\title{
Change of the Physical Properties of Coloured High Density Polyethylene by Effect of Environment
}

\section{Shady KE* and Tera FM}

National Institute for Standards Giza, Egypt

\begin{abstract}
This study deals with the environment and different liquid environments which have effect on both the colour fastness and the mechanical properties - which can be expressed as tensile strength and elongation - of coloured high density polyethylene polymer in net form , used for warning and used as an indicator for the undo ground pipes passage. It was found that withering affects shows that the tensile strength and the elongation considerably, while change on temperature of the surroundings was found to show less effect. Also, environment liquids caused a small loss in tensile strength of about (6\%) while the samples in extended percent or about $(22 \%)$ was observed.
\end{abstract}

Both parameters were showed an appreciable change at damped soiling mud. The light fastness of the examined polymer samples were greatly affected by weathering conditions, while the other factors did not affect the light fastness considerably.

Keywords: Liquid environments; Polyethylene polymer; Ground pipes

\section{Introduction}

Environmental conditions exposure on the high polymers causes molecular chain scission at the exposed surface, serious reduction in mechanical properties, discoloration and fading [1-4]. The most responsible weather features for photo degradation are light particularly of near ultraviolet wave length $[5,6]$, moisture in the liquid of vapour form, temperature and oxygen [6,7]. The rate of photochemical degradation is greatly increased with the temperatures and moisture of the surroundings. The polyethylene showed high resistance to chemical, moisture and other environments.

This work studied and discussed the change in the mechanical properties and colour of orange high density polyethylene polymer in the net form produced by the effect of different environmental conditions and liquids. The traditional polymer materials available today, especially the plastics, are the result of decades of evolution. Their production is extremely efficient in terms of utilization of raw materials and energy, as well as of waste release. The products present a series of excellent properties such as impermeability to water and microorganisms, high mechanical strength, low density (useful for transporting goods), and low cost due to manufacturing scale and process optimization. However, some of their most useful features, the chemical, physical and biological inertness, and durability resulted in their accumulation in the environment if not recycled. Unfortunately, the accumulation of plastics, along with other materials, is becoming a serious problem for all countries in the world. These materials occupy significant volume in landfills and dumps today. Recently, the presence of huge amounts of plastic fragments on the oceans has been observed, considerable part of them coming from the streets, going through the drains with the rain, and then going into the rivers and lakes, and then to the oceans. As a result, there is a very strong and irreversible movement, in all countries of the world, to use materials that do not harm the planet, that is, low environmental impact materials [8].

Biodegradability is a feature that has been highly valued in polymers from the environmental standpoint, but is not the only important one. Sooner or later, all components in a polymer material will be returned to the environment, with the degradation, so it is very important to use pigments, fillers and additives that are not toxic in nature. Furthermore, the environmental impacts should be studied from birth to death of the polymer (or "from cradle to grave"). The use of raw materials from renewable resources (plants) has also been highlighted. However, one point to be considered here is the use of arable land for monocultures in farms that could be producing food and are instead producing raw materials for commodities (like plastics). Likewise, one must consider the possibility of using fertilizers and pesticides in excess, what could impact in eutrophication, acidification, global warming, poisoning of the environment, etc. Another point is to know if the farming practices are conservationists or not, i.e. if they seek to preserve the soil or not. For example, the practice of burning crop residues after harvest should be avoided. Another interesting aspect is the one of polymer production. Very complex processes with many steps, which consume much energy and generate much waste, tend to be disadvantaged. The need for transportation of raw materials to the factory or of finished products to the consumer market must also be considered. All the characteristics above are usually considered in the life cycle assessment of the product, which, being somewhat complex, can be aided by regulatory standards (e.g. series EN-ISO 14040) [9].

\section{Experimental}

\section{Samples}

Orange $1 \backslash 2$ nets, high - density polyethylene polymer supplied by the Egyptian company for synthetic fibres, Egypt, was used. Ten samples were taken as a set for each test.

\section{Weathering}

*Corresponding author: Shady KE, National Institute for Standards Giza, Egypt, Tel: 202 33889783; E-mail: shadykamals@yahoo.com

Received September 25, 2014; Accepted July 24, 2015; Published July 30, 2015

Citation: Shady KE, Tera FM (2015) Change of the Physical Properties of Coloured High Density Polyethylene by Effect of Environment. J Material Sci Eng 4: 184. doi:10.4172/2169-0022.1000184

Copyright: @ $\odot 2015$ Shady KE, et al. This is an open-access article distributed unde the terms of the Creative Commons Attribution License, which permits unrestricted use, distribution, and reproduction in any medium, provided the original author and source are credited. 
A group of samples were exposed directly to environmental conditions at an urban site on Egypt for one month. A blue scale was hanged alongside with the samples for the same exposer period.

\section{Environmental liquids}

a) Tap water was used to immerse the samples in continuously for 30 days.

b) A set of samples were immersed in an acid solution where $\mathrm{pH}$ is 5.5 for the same period.

c) Another set of the samples were immersed in an alkaline solution whose $\mathrm{pH}$ is 9 for the same period.

\section{Soil burying}

a) Muel-soil burying: Strips of the examined samples were buried during February 2013 in a damped mud soil at a depth of $40 \mathrm{~cm}$.

b) Sand-soil burying: Another set of strip samples were buried in sand-soil for the same period the same depth.

\section{Heating}

a) Damped - hot surroundings: Set of strip samples were dipper in ajar, kept in an oven whose temperature was $40^{\circ} \mathrm{C}$ for ten hours, and another set were kept at $70^{\circ} \mathrm{C}$ for the same time.

b) Dry - hot surrounding: A group of the examined samples were left in an oven kept at $50^{\circ} \mathrm{C}$ for 10 hours.

\section{Testing}

a) Mechanical properties: All sets of samples were removed to a test room Conditioned at a temperature of $23^{\circ} \mathrm{C}$ and R.H of $65 \%$ for 24 hours changes in tensile, height and elongation \% were assessed by tensile tester (C.R.T).

b) Light fastness: Visual assessment of light fastness was performed to all sets of examined samples.

\section{Results and Discussion}

\section{Weathering}

Considering the results of Table 1, we may notice clearly that exposing the orange net high density polyethylene samples directly to environmental conditions caused a considerable change in the mechanical properties, where a loss in tensile strength of about $10 \%$ was recorded. While, that of the extension, was higher and reached about
$50 \%$. In addition the light fastness values decreased and became 4 only. Blue scale this findings call for the fact that these nets must be used for the underground warning only since both the mechanical properties and the colour fastness were changed greatly by such exposure.

\section{Environment liquids}

On the other hand, the environment liquids showed an appreciable decrease in the tensile strength when the samples were immersed- for one month- in any of the tap water or either the acidic or alkaline solution. It can be seen clearly that the aqueous solution produced a considerable increment in the elongation percent of about $24 \%$ and this may be attributed to swelling of the polymer. The same effect was observed when the polymer was immersed in either acidic or alkaline solution. In addition, the environment liquids caused a noticeable change in colour after immersion for one month.

\section{Soil burying}

Mud-soil burying: It is clear that the examined polymer suffered a small change in either the mechanical properties or colour fastness by such a test.

Sand-soil burying: The examined sample showed the least change in all parameter.

\section{Heating}

a) Damped-hot surroundings: Raise in temperature of the surroundings ( 40 and $70^{\circ} \mathrm{C}$ ) was accompanied by an increase with tensile strength of about (5-7\%) and a decrease in the elongation of about $6 \%$ while the colour was almost unaffected.

b) Dry-hot surroundings: Dry-hot surroundings at $50^{\circ} \mathrm{C}$ caused the same change in tensile strength as that of the damped one, while, for the elongation \%, the decrease was higher of about $9 \%$ indicating that the polymer became more brittle. Also, an appreciable change in colour was observed after such a test.

\section{Conclusion}

Coloured high-density polyethylene nets may be used safely for warning and as an indicator for the underground pipes passage. Its colour, also the mechanical properties are appreciable changed when exposed to severe conditions of environment liquids in the underground.

On the other hand, direct exposure to environmental conditions (weathering) was accompanied by a change in the mechanical

\begin{tabular}{|c|c|c|c|c|}
\hline \multirow[t]{2}{*}{ Type of testing } & \multicolumn{2}{|c|}{ Mechanical properties } & \multirow{2}{*}{$\begin{array}{l}\text { Light fastness values } \\
\text { (Blue scale) }\end{array}$} & \multirow[t]{2}{*}{ Visual color change } \\
\hline & $\begin{array}{c}\text { Changes in T.S } \\
\text { (Tensile strength) \% }\end{array}$ & Changes in $E \%$ & & \\
\hline 1. Weathering & 10 & 50 & 4 & Considerable change \\
\hline $\begin{array}{l}\text { 2. Environment liquids } \\
\text { a. Tab Water } \\
\text { b. acidic solution } \\
\text { c. alkaline solution }\end{array}$ & $\begin{array}{l}5 \\
6 \\
5\end{array}$ & $\begin{array}{l}24 \\
20 \\
22\end{array}$ & ------ & $\begin{array}{l}\text { Noticeable change } \\
\text { Noticeable change } \\
\text { Noticeable change }\end{array}$ \\
\hline $\begin{array}{l}\text { 3. a. mud-soil burying } \\
\text { b. sand-soil burying }\end{array}$ & $\begin{array}{c}-3 \\
0\end{array}$ & $\begin{array}{c}-4 \\
1\end{array}$ & ----- & $\begin{array}{l}\text { Appreciable change } \\
\text { Appreciable change }\end{array}$ \\
\hline $\begin{array}{l}\text { 4. a. Damped-hot surrounding } \mathrm{t} \\
\text { at } 40^{\circ} \mathrm{C} \\
\text { at } 70^{\circ} \mathrm{C} \\
\text { b. Dry-hot surrounding } \\
\text { at } 50^{\circ} \mathrm{C}\end{array}$ & $\begin{array}{l}5 \\
7 \\
5\end{array}$ & $\begin{array}{l}6 \\
6 \\
-9\end{array}$ & ----- & $\begin{array}{l}\text { Appreciable change } \\
\text { Appreciable change } \\
\text { Appreciable change }\end{array}$ \\
\hline
\end{tabular}

Table 1: Shows results of weathering 
Citation: Shady KE, Tera FM (2015) Change of the Physical Properties of Coloured High Density Polyethylene by Effect of Environment. J Material Sci Eng 4: 184. doi:10.4172/2169-0022.1000184

Page 3 of 3

properties where the tensile strength suffered a loss of about $20 \%$, while for elongation the loss was about $50 \%$. Nevertheless, the light fastness values were reduced to 4 . This findings call to the fact that when using such a polymer in the underground sites, it must be used directly there and not to be left to weathering conditions.

\section{References}

1. Shady KE (1983) Damage measurements of some unfinished textile fabrics due to weathering conditions in Egypt. Textile department, Helwan University, Cairo.

2. Cheng JJ, Polak MA, Penlidis A (2011) Influence of micro molecular structure on environmental stress cracking resistance of high density polyethylene. Tunneling and Underground Space Technology 26: 582-593.

3. Reis JML, Pacheco LJ, Mattos HSC (2013) Influence of the temperature and strain rate on the tensile behaviour of post consumer recycled high-density polyethylene. Polymer Testing 32: 1576-1581.

4. Rugger GR, Rosato DV, Swartz J (1998) Investigation of automated geometry modelling process of woven fabrics based on the yarn structures. Interscience 40: 339-342.

5. Shah CD, Srinivasan R (1975) A Study of light damage to undyed textile yarns under a fading lamp at a fixed humidity. J Textile Inst 66: 249-254.

6. Shah CD, Srinivasan R (1998) Determination of mineral content in polymelt nonwoven fabrics. J Textile Inst 5: 99 -103.

7. Egerton G, Shah CD (1998) Impact of polyurethane yarns on the mechanical properties of braided artificial ligaments. Textile Res J 38130.

8. Shady KE (1989) Scientific aspects of the different changes occurring to some textile fabrics after exposure to various irradiation sources. Textile Department Helwan University, Cairo.

9. Moore WR (1995) An Introduction to polymer chemistry. (2ndEdn) John Wiley and sons. 